\title{
The Invertase Activity of Rabbit Small Intestine
}

\author{
By J. A. CARNIE* AND J. W. PORTEOUS \\ Department of Biological Chemistry, Marischal College, University of Aberdeen
}

(Received 27 April 1962)

Most recent publications describing the properties of invertase refer to enzyme preparations obtained from plants, bacteria, fungi, protozoa or the honey bee (Edelman, 1956; Allen \& Bacon, 1956; Pavlinova \& Kursanov, 1956; Christie \& Porteous, 1957; Carnie \& Porteous, 1959 $a$; Howard, 1959). Borgström \& Dahlqvist (1958), Dahlqvist \& Borgström (1959) and Dahlqvist $(1958,1959 a-c, 1960 a-f, 1961)$ have provided the only recent systematic accounts of the properties of an invertase obtained from an animal source, namely hog intestine.

The characterization of the invertase activity of the mucosal cells of rabbit small intestine is now described. A brief account of some of the work has been published (Carnie \& Porteous, 1959b).

\section{EXPERIMENTAL}

Animals. Dutch rabbits of either sex and weighing 1.5$3.0 \mathrm{~kg}$. were kept on a diet of cabbage, rabbit cake and water for several days before an experiment. For the $24 \mathrm{hr}$. before an experiment all solid food was withheld, the cages were cleaned of faeces twice during the starvation period, but water was allowed ad libitum. The primary purpose of starvation was to free the small intestine of partially digested food.

Isolation of mucosal cells of small intestine. A single rabbit was used for each experiment and killed under light chloroform anaesthesia by a sharp blow across the neck. The complete small intestine was rapidly excised and transferred to chipped ice. The chilled intestine was cut into approximately $15 \mathrm{~cm}$. lengths, fat and omentum were trimmed away and the lumen was washed out with $0.9 \%$ $\mathrm{NaCl}$ or with $0.25 \mathrm{M}$-sucrose at $2^{\circ}$. Each length of trimmed and washed intestine was cut open longitudinally, laid mucosal side uppermost on a cold glass plate and the mucosal layer removed with the aid of a glass slide into a tared beaker immersed in chipped ice. All subsequent manipulations were carried out in pre-cooled vessels immersed in chipped ice or contained in centrifuges operated at $2-5^{\circ}$.

Cell homogenization. The weighed mucosal cell preparation (usually $30 \mathrm{~g}$.) was suspended in 4 vol. of ice-cold freshly prepared $0.25 \mathrm{M}$-sucrose. This suspension was treated in a Waring Blendor at approximately 7500 rev./ min. for $1 \mathrm{~min}$., then for four $1 \mathrm{~min}$. periods at approximately $15000 \mathrm{rev} . / \mathrm{min}$. with $15 \mathrm{sec}$. intervals between each maceration.

\footnotetext{
* Present address: Department of Biochemistry, Manchester College of Science and Technology, Manchester 2.
}

Centrifuging. The disrupted cell preparation was centrifuged at $10000 \mathrm{~g}$ for $15 \mathrm{~min}$. (MSE 13 centrifuge, rotor no. 69142), the sediment discarded and the supernatant suspension centrifuged at $100000 \mathrm{~g}$ for $45 \mathrm{~min}$. (Spinco model L centrifuge, rotor no. 40). The supernatant solution (which was free of invertase activity) was removed. The sediment (hereafter called the $10^{5} \mathrm{~g}$ fraction) was used as the source of enzyme for further experiments.

Reagents. Sucrose, lactose and glucose were AnalaR reagents (British Drug Houses Ltd.); fructose was obtained from Hopkin and Williams Ltd., turanose from British Drug Houses Ltd. and maltose from Thomas Kerfoot, Ashton-under-Lyne, Lancs. Uniformly (U) labelled [U-14 C]glucose and [U-14 C]fructose, specific activity $20 \mu \mathrm{c} / \mathrm{mg}$., were obtained from The Radiochemical Centre, Amersham, Bucks. All sugars except maltose (which contained a trace of maltotriose) were pure when tested by the chromatographic procedure detailed below. Sodium dihydrogen phosphate dihydrate, $\mathrm{KH}_{2} \mathrm{PO}_{4},\left(\mathrm{NH}_{4}\right)_{2} \mathrm{SO}_{4}$, trichloroacetic acid, sodium acetate, trihydrate and acetic acid were AnalaR reagents. Sodium deoxycholate was purchased from Hopkin and Williams Ltd. Butan-1-ol was fractionally redistilled before use; ethanol was refluxed over $\mathrm{KOH}$ and distilled from $\mathrm{CaO}$.

Chromatography. Sugars were separated by descending chromatography at $22-24^{\circ}$ during $24-36 \mathrm{hr}$. on Whatman no. 54 paper with the butan-1-ol-acetic acid-water $(4: 1: 5$, by vol.) solvent of Partridge (1948). Where samples from an enzyme-catalysed reaction were to be chromatographed the starting points of the chromatogram were pretreated with $5 \mu$ l. of $0.01 \mathrm{M}-\mathrm{HgCl}_{2}$ to stop enzyme activity. Each starting point normally received $5-10 \mu \mathrm{l}$. of a solution that contained initially $0 \cdot 1-0.5 \mathrm{M}$-sucrose. Free and combined monosaccharides were detected on air-dried chromatograms with the benzidine-trichloroacetic acid reagent of Bacon \& Edelman (1951). Free and combined ketoses were detected with the urea-phosphoric acid reagent of Wise, Dimler, Rist \& Davis (1955).

Radioactivity measurements. ${ }^{14} \mathrm{C}-L a b e l l e d$ sugars separated by paper chromatography were located with the benzidine-trichloroacetic acid spray reagent. A vertical line, representing the track of the chromatographically separated sugars, was drawn from the starting point to the lower end of the paper. Two parallel lines were drawn $1.5 \mathrm{~cm}$. on either side of this line and the resulting strip of paper was cut along horizontal lines spaced at $1.5 \mathrm{~cm}$. intervals to give serial sections of paper, $1.5 \mathrm{~cm} . \times 3.0 \mathrm{~cm}$. Each section was bisected and the radioactivity of each square of paper determined with a halogen-quenched endwindow Geiger-Müller counter and a type N 530D autoscaler (Ekco Electronics Ltd., Essex). Since the activities of different areas of the chromatograms were expected to differ widely the time required to record 300 counts was determined for each square of paper; these values were converted into counts/min. and corrected for the back- 
ground count. Scanning and spraying of the residual chromatogram showed that all radioactive and benzidinepositive material had been accounted for.

Determinations of $\mathrm{pH}$. All measurements were made at 18-20 with a Model $30 \mathrm{pH}$ meter (Electronic Instruments Ltd., Richmond, Surrey) standardized at the same temperature.

Determinations of total nitrogen. Samples were analysed by $\mathrm{Kjeldahl}$ digestion for 18-24 hr. with the catalyst of Chibnall, Rees \& Williams (1943), followed by distillation (Markham, 1942) of the $\mathrm{NH}_{8}$ under alkaline conditions into boric acid-bromocresol green-methyl red solution (Conway \& O'Malley, 1942) and titration of the trapped $\mathrm{NH}_{3}$ with approximately $0.01 \mathrm{~N}-\mathrm{H}_{2} \mathrm{SO}_{4}$.

Determinations of free reducing sugar. Eluates from chromatograms and samples from enzyme-assay systems were analysed for free reducing sugars by the colorimetric method of Nelson (1944). Glucose and fructose gave identical calibration curves.

Determinations of total reducing sugar. Eluates from chromatograms were subjected to hydrolysis in $0 \cdot 25 \mathrm{~N}-\mathrm{HCl}$ or in $0.5 \%$ oxalic acid at $100^{\circ}$ for $30-60 \mathrm{~min}$. followed by neutralization of the cold hydrolysate with 0.25 or $0.22 \mathrm{~N}$ $\mathrm{NaOH}$, respectively. The neutralized solution, after being made to a known volume with water, was analysed for reducing sugar as detailed above.

Determinations of total fructose. Eluates from chromatograms were analysed by the colorimetric method of Roe, Epstein \& Goldstein (1949).

Assay of invertase activity. In assaying the invertase activity of the $10^{5} \mathrm{~g}$ fraction and subfractions, in determining the kinetic characteristics of partly purified invertase and in experiments concerned with the formation of oligosaccharides by a partially purified invertase, deproteinization of samples removed from the incubation system was found to be unnecessary. Buffered substrate was preincubated at $37^{\circ}$ for $10 \mathrm{~min}$. Addition of the enzyme preparation (at $2^{\circ}$ ) brought the volume to $5 \mathrm{ml}$. Two controls were always incubated at the same time, one without enzyme and one without substrate. After incubation at $37^{\circ}$ for a known time samples were measured directly into $2 \mathrm{ml}$. of the alkaline $\mathrm{CuSO}_{4}$ reagent (Nelson, 1944); enzyme activity was thus terminated immediately. The contents of the Nelson reaction tubes were made to $4 \mathrm{ml}$. with water before the determination of free reducing sugars.

In using this system to determine optimum conditions for the assay of the hydrolytic activity of the enzyme the composition and $\mathrm{pH}$ of the buffer, the substrate concentration, the enzyme concentration and the time of incubation were varied in turn. In following oligosaccharide formation in this system the $\mathrm{pH}$ was held at 6.7 in $0.04 \mathrm{M}-\mathrm{Na}_{2} \mathrm{HPO}_{4}-$ $\mathrm{NaH}_{2} \mathrm{PO}_{4}$ buffer; the initial substrate concentration and the time of incubation at $37^{\circ}$ were varied as stated in the text.

Enzyme unit. An invertase unit is defined as the amount of enzyme required to produce $1 \mu$ mole of free hexose from

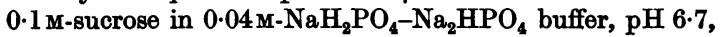
when incubated at $37^{\circ}$ for $60 \mathrm{~min}$.

Specific enzyme activities. These are expressed as the number of enzyme units/mg. of total nitrogen.

\section{RESULTS}

Stabilization of the invertase activity. The particulate invertase preparation $\left(10^{5} \mathrm{~g}\right.$ fraction) lost approximately $\mathbf{5 0} \%$ of its activity on storage for 1 week at $-20^{\circ}$; attempts to stabilize the activity were combined with attempts to solubilize the enzyme. The $10^{5} \mathrm{~g}$ fraction from $20 \mathrm{~g}$. of mucosal cells was suspended in $100 \mathrm{ml}$. of water and dialysed for $48 \mathrm{hr}$. at $2^{\circ}$ against distilled water; the nondiffusible material was termed fraction 1. A similar portion of the $10^{5} \mathrm{~g}$ fraction was suspended in $100 \mathrm{ml}$. of sodium deoxycholate $(0.5 \%)$ at $\mathrm{pH} 7.5$ in $0.1 \mathrm{M}-\mathrm{KH}_{2} \mathrm{PO}_{4}-\mathrm{Na}_{2} \mathrm{HPO}_{4}$ buffer at $2^{\circ}$ for $5 \mathrm{~min}$. Centrifuging $\left(100000 \mathrm{~g}\right.$ for $60 \mathrm{~min}$. at $2^{\circ}$ ) yielded a clear supernatant extract, which after dialysis as before gave fraction 2 with a 1.7-fold increase in activity over fraction 1. Approximately $80 \%$ of the activity of fraction 2 was retained in the supernatant (fraction 3) when fraction 2 was stored at $-20^{\circ}$ for $24 \mathrm{hr}$., thawed and centrifuged (100 $000 \mathrm{~g}$ for $60 \mathrm{~min}$. at $2^{\circ}$ ); the remainder of the activity was recovered from the sediment. A further portion of the deoxycholate extract (before dialysis) was incubated for $10 \mathrm{~min}$. at $37^{\circ}$ with $\frac{1}{3}$ vol. of butan-1ol, centrifuged ( $1000 \mathrm{~g}$ for $20 \mathrm{~min}$. at $2^{\circ}$ ) and the aqueous layer dialysed as before. The non-diffusible material contained the same number of enzyme units as did fraction 1. Storage of this material at $-20^{\circ}$, followed by thawing and centrifuging ( $100000 \mathrm{~g}$ for $60 \mathrm{~min}$. at $2^{\circ}$ ), yielded a clear supernatant (fraction 4) containing $60 \%$ of the activity of fraction 1 ; the remainder of the activity was recovered from the sediment. Fraction 3 (specific activity 70) and fraction 4 (specific activity 180) appeared to contain the invertase in solution. Fraction 1, when treated with butan-1-ol, gave an aqueous layer which, after dialysis, was devoid of enzyme activity.

Fractions 3 and 4 retained all their invertase activity for at least 10 days when stored at $2^{\circ}$, and for several weeks when stored at $-20^{\circ}$, although both fractions became slightly turbid on thawing. Fraction 3 when freshly isolated became slightly turbid under enzyme-assay conditions whereas fraction 4 remained water-clear under the same conditions.

Kinetic characteristics of the invertase. Fraction 4 was used to determine the kinetic characteristics of the invertase and the optimum conditions for its assay. The hydrolytic activity of the invertase was optimum at pH 6.7 (Fig. 1). The hydrolytic activity-substrate concentration plot for the enzyme (Fig. 2) showed that at pH 6.7 the enzyme became saturated with substrate at a concentration of 0.1 M-sucrose. A double-reciprocal plot (Lineweaver \& Burk, 1934) of the data shown in Fig. 2 was consistent with the formation of a substrateactivated enzymo-substrate complex (Dixon \& Webb, 1958). A linear double-reciprocal plot, obtained over a restricted range of substrate concentration, is shown in Fig. 3, from which apparent 
$K_{m} 6.2 \mathrm{~mm}$-sucrose and $V_{\max } .3 \cdot 2 \mu$ moles of reducing sugar $/ \mathrm{hr}$. were determined.

At pH 6.7 (0.04 M-sodium phosphate buffer) and with an initial sucrose concentration of $0.1 \mathrm{M}$ it was further shown that hydrolytic activity was proportional to enzyme concentration over a tenfold range of enzyme concentration and that hydrolysis was proportional to time for at least $120 \mathrm{~min}$.

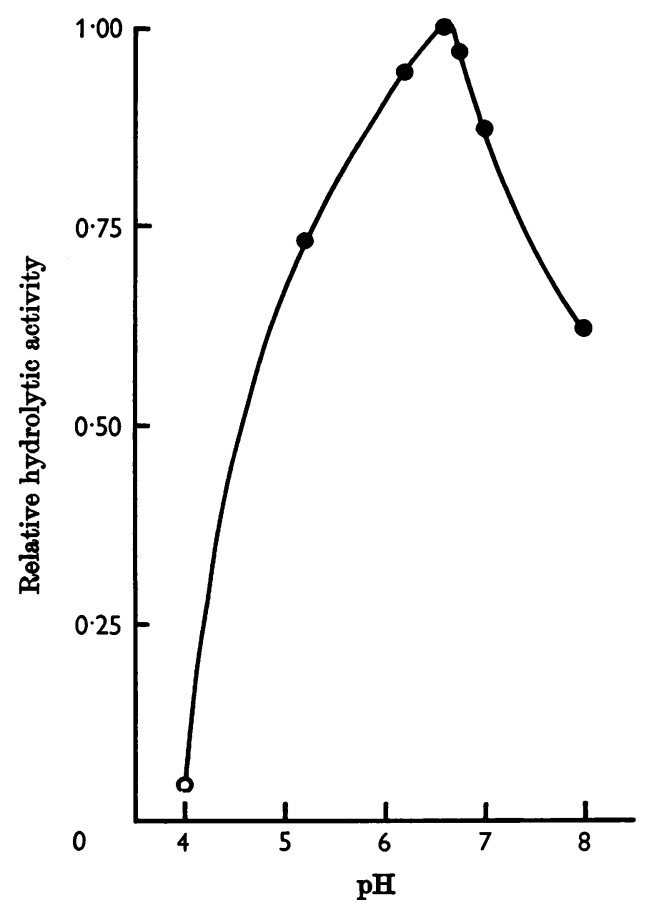

Fig. 1. Effect of $\mathrm{pH}$ on the hydrolytic activity of an invertase preparation (fraction 4) obtained from the mucosal cells of rabbit small intestine. Incubation was for $60 \mathrm{~min}$. Phosphate buffers (described in the Experimental section); $O, 0.04 \mathrm{M}$-acetate buffer.

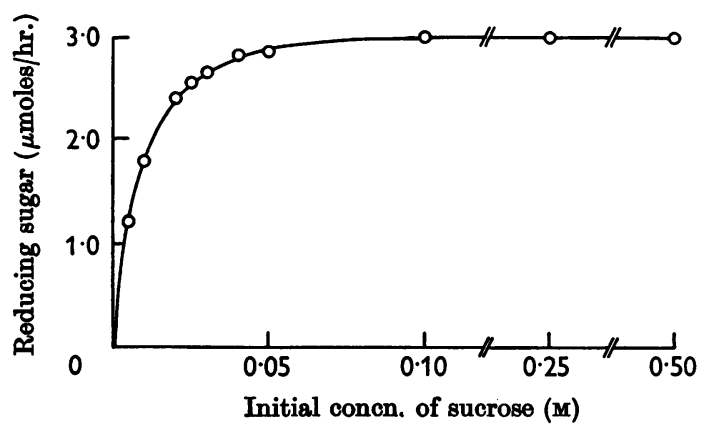

Fig. 2. Effect of sucrose concentration on the hydrolysis of sucrose by an invertase preparation (fraction 4) obtained from the mucosal cells of rabbit small intestine. Incubation was for $60 \mathrm{~min}$., with phosphate buffer, pH 6.7 (see Fig.1).
From these data the optimum conditions used for enzyme assay were established. The enzyme concentration was always adjusted, unless otherwise stated, so that no more than $6 \%$ of the initial substrate was hydrolysed.

In separate experiments it was shown that replacement of the $\mathrm{Na}_{2} \mathrm{HPO}_{4}-\mathrm{NaH}_{2} \mathrm{PO}_{4}$ buffer, $\mathrm{pH} \mathrm{6.7,} \mathrm{by} \mathrm{Na}_{2} \mathrm{HPO}_{4}-\mathrm{KH}_{2} \mathrm{PO}_{4}$ buffer of the same molarity and $\mathrm{pH}$ value decreased the activity of the enzyme by approximately $30 \%$. This effect has not been further investigated.

Oligosaccharide formation by an intestinal invertase preparation. The $10^{5} \mathrm{~g}$ fraction, fraction 3 and fraction 4 contained maltase, invertase and trehalase activity (Carnie \& Porteous, 1962).

Incubation of fraction 3 enzyme with sucrose in 0.04 M-phosphate buffer, pH 6.7, followed by chromatographic separation of the substrate and reaction products, showed that sucrose, glucose, fructose and a single oligosaccharide with a mobility 0.6 of that of sucrose $\left(R_{\text {sucrose }} 0.6\right)$ could be detected with the benzidine spray reagent. This oligosaccharide gave a positive (brown) reaction to the benzidine spray reagent and a blue reaction with the urea-phosphoric acid reagent, which indicated that it contained both aldose and ketose sugars. The results of several experiments are shown in Table 1. Oligosaccharide formation increased with increasing initial substrate concentration; for a given initial substrate concentration oligosaccharide formation at first increased with time of incubation, then decreased again. This latter semi-quantitative observation is consistent with the quantitative results of Bealing \& Bacon (1953), who showed that oligosaccharides formed by mould invertase are themselves hydrolysed by the enzyme.

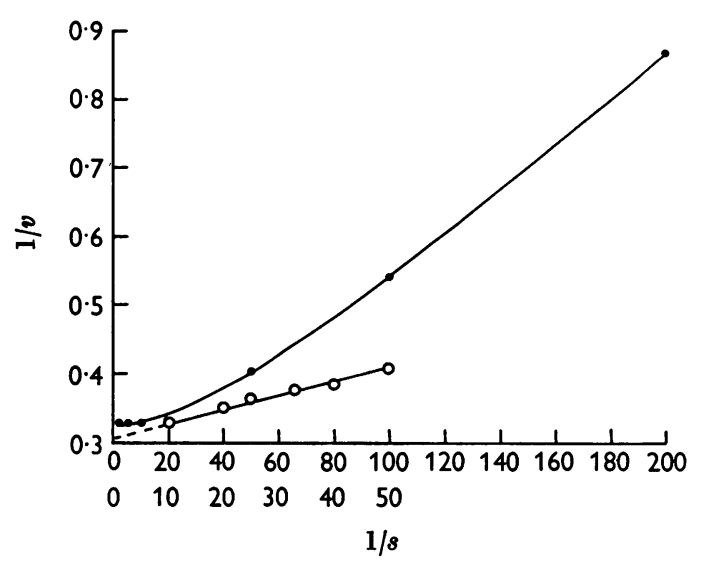

Fig. 3. Lineweaver-Burk plot of data shown in Fig. 2. -. Data obtained over the range 0.005-0.5 M-sucrose (upper abscissa); $O$, data obtained over the range 0.020.1 M-sucrose (lower abscissa). 
A trace of a second oligosaccharide $\left(R_{\text {Sucrose }} 0 \cdot 25\right)$ was occasionally detected with the benzidine spray reagent when the enzyme was incubated with $0.5 \mathrm{M}$-sucrose until approximately $17 \%$ apparent hydrolysis of initial substrate had occurred.

In the above-mentioned experiments, samples taken from the two control tubes of the assay system failed to show the presence of any oligosaccharide and none was found when the enzyme was incubated with a mixture of glucose and fructose in the absence of sucrose.

In an incubation system containing $10 \%(\mathrm{v} / \mathrm{v})$ of ethanol and $0 \cdot 1 \mathrm{M}$-sucrose neither ethyl glucoside nor ethyl fructoside was produced by the enzyme and no inhibition of apparent hydrolytic activity occurred (cf. Bacon, 1952; Bealing, 1953; Christie \& Porteous, 1957).

Incubation of the same enzyme preparation with $0 \cdot 1 \mathrm{M}$-maltose in place of sucrose gave free glucose and two oligosaccharides, neither of which was identical (as judged by chromatographic mobility and reaction to spray reagents) with those formed from sucrose. That with greater mobility was possibly maltotriose since it appeared in the same position as the impurity in maltose. The other oligosaccharide was possibly a tetrasaccharide. Neither was analysed. When $0 \cdot 1 \mathrm{~m}$-lactose replaced sucrose in the incubation system neither hydrolysis nor oligosaccharide formation could be detected.

The formation of the oligosaccharide $\left(R_{\text {sucrose }} 0 \cdot 6\right)$ from sucrose and of two oligosaccharides from maltose was confirmed when fraction 4 enzyme replaced fraction 3 enzyme in similar experiments.

Analysis of the oligosaccharide $\left(R_{\text {sucrose }} \quad 0 \cdot 6\right)$ formed from $0.5 \mathrm{M}$-sucrose by fraction 3 enzyme in four experiments and eluted from chromatograms by the method of Dent, Stepka \& Steward (1947) gave the results shown in Table 2. In Expts. 1 and 2 the apparent free reducing sugar values accounted for approximately $5 \%$ of the total reducing sugar; in Expts. 3 and 4 the corresponding value was $2 \%$. The free reducing sugar values in Expts. 2,
3 and 4 (Table 2) were within the limits of error of the analytical procedure. It appeared therefore that the oligosaccharide had poor reducing power or was a non-reducing sugar that accounted for $3-4 \%$ of all sugars present in the incubation system (Table 2). Separate experiments showed that under the conditions of hydrolysis used in Expts. 1 and 2 (Table 2) the oligosaccharide was completely hydrolysed to glucose and fructose only. Under the conditions of hydrolysis used in Expts. 3 and 4 (Table 2) a trace of the oligosaccharide remained, the other products being glucose and fructose only. On the assumption that the small amount of apparent free reducing sugar (Table 2) could be ignored, the glucose content of the oligosaccharide was obtained as the difference between the total reducing sugar and the total fructose determinations. The ratio of glucose to fructose was thus determined in the four experiments as $1.32,1 \cdot 16,0 \cdot 82,0.90$. The first of these values did not take account of any sugars present in the chromatographic paper (Table 2); the mean of the three other determinations is $\mathbf{0 . 9 6}$.

Incorporation of $\left[\mathrm{U}^{-14} \mathrm{C}\right]$ glucose and of $\left[\mathrm{U}-{ }^{14} \mathrm{C}\right]$ fructose into the products of action of invertase on sucrose. Four reaction tubes were set up containing

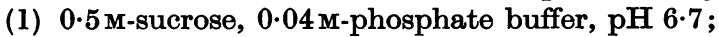
(2) as (1) but with $30 \mu \mathrm{C}$ of [U-14 C]fructose (about $1.5 \mathrm{mg}$.) added initially; (3) as (1) but with $30 \mu \mathrm{C}$ of [U. ${ }^{14} \mathrm{C}$ ]glucose (about $1.5 \mathrm{mg}$.) added initially; (4) as (1) but with sucrose omitted and replaced by $0.5 \mathrm{M}$-glucose and 0.5 M-fructose. A drop of toluene and of chloroform was added to each tube and the contents were incubated at $37^{\circ}$ for $5 \mathrm{~min}$. before bringing the volume to $1 \mathrm{ml}$. by adding to each a dialysed deoxycholate extract of the $10^{5} \mathrm{~g}$ fraction of mucosal cells (fraction 2). After incubation for $24 \mathrm{hr}$., $10 \%$ apparent hydrolysis of the sucrose had occurred; a sample $(5 \mu \mathrm{l}$.) was removed from each incubation tube and applied to chromatograms, which were prepared, developed, sprayed and cut into sections as described above.

\section{Table 1. Oligosaccharide formation at various sucrose concentrations}

Fraction 3 invertase was incubated with different initial concentrations of sucrose for various times at $37^{\circ}$ and pH 6.7 and the amount of oligosaccharide $\left(R_{\text {Sucrose }} 0 \cdot 6\right)$ estimated. 0 , Relative amounts of nligosaccharide formed as judged visually from spot size and intensity. H, Apparent hydrolysis (\%) as determined by direct analysis of reaction mixture for free reducing sugars.

Amount of oligosaccharide formed

Initial sucrose conen. (M) ... Incubation time

(hr.)

2

4

5

10

12

24

\begin{tabular}{ll}
$\overbrace{0}^{0.05}$ & \\
\hline 0 & $\frac{17}{0}$ \\
\hline 0 & $\frac{12}{40}$ \\
\hline 0 & $\frac{80}{2}$
\end{tabular}

\begin{tabular}{|c|c|c|c|c|c|}
\hline \multicolumn{2}{|c|}{$0 \cdot 1$} & \multicolumn{2}{|c|}{0.25} & \multicolumn{2}{|c|}{0.5} \\
\hline 0 & $\mathbf{H}$ & 0 & $\mathbf{H}$ & 0 & $\mathbf{H}$ \\
\hline- & - & - & - & - & - \\
\hline 1 & - & - & - & - & - \\
\hline - & 23 & - & - & - & $3 \cdot 7$ \\
\hline 2 & 39 & - & - & - & $\bar{u}$ \\
\hline 3 & 45 & 3 & 23 & 2 & 10 \\
\hline 1 & 85 & 4 & 45 & 16 & 20 \\
\hline
\end{tabular}


Table 2. Analysis of the oligosaccharide $\left(R_{\text {sucrose }} 0 \cdot 6\right)$

Sucrose (0.5 M) was incubated at $37^{\circ}$ and $\mathrm{pH} 6.7$ for $24 \mathrm{hr}$. with fraction 3 enzyme until 11-17\% apparent hydrolysis had occurred (Table 1). In Expt. 1, $5 \mu$ l. of the incubation system was applied to each of 20 separate points along the starting line of a chromatogram; in the other three experiments $5 \mu$ l. was applied to each of eight points. Values quoted refer to the total oligosaccharide subsequently eluted from the individual chromatograms. Total reducing sugar was determined after hydrolysis with $\mathrm{HCl}$ (Expts. 1 and 2) or with oxalic acid (Expts. 3 and 4).

\begin{tabular}{|c|c|c|c|c|}
\hline Expt. & & $\begin{array}{c}\text { Free reducing } \\
\text { sugar } \\
\text { (as glucose) } \\
(\mu \mathrm{g} .)\end{array}$ & $\begin{array}{c}\text { Total reducing } \\
\text { sugar } \\
\text { (as glucose) } \\
(\mu \mathrm{g} .)\end{array}$ & $\begin{array}{l}\text { Total ketose } \\
\text { (as fructose) } \\
(\mu \mathrm{g} .)\end{array}$ \\
\hline 1 & $\begin{array}{l}\text { Oligosaccharide } \\
\text { Paper blank }\end{array}$ & 40 & 744 & \\
\hline & Net & 40 & 744 & 320 \\
\hline 2 & $\begin{array}{l}\text { Oligosaccharide } \\
\text { Paper blank } \\
\text { Net }\end{array}$ & $\begin{array}{l}24 \\
12 \\
12\end{array}$ & $\begin{array}{r}280 \\
12 \\
268\end{array}$ & $\begin{array}{r}128 \\
4 \\
124\end{array}$ \\
\hline 3 & $\begin{array}{l}\text { Oligosaccharide } \\
\text { Paper blank } \\
\text { Net }\end{array}$ & $\begin{array}{r}12 \\
8 \\
4\end{array}$ & $\begin{array}{r}220 \\
16 \\
204\end{array}$ & $\begin{array}{r}120 \\
8 \\
112\end{array}$ \\
\hline 4 & $\begin{array}{l}\text { Oligosaccharide } \\
\text { Paper blank } \\
\text { Net }\end{array}$ & $\begin{array}{l}4 \\
0 \\
4\end{array}$ & $\begin{array}{r}236 \\
8 \\
228\end{array}$ & $\begin{array}{r}128 \\
8 \\
120\end{array}$ \\
\hline
\end{tabular}

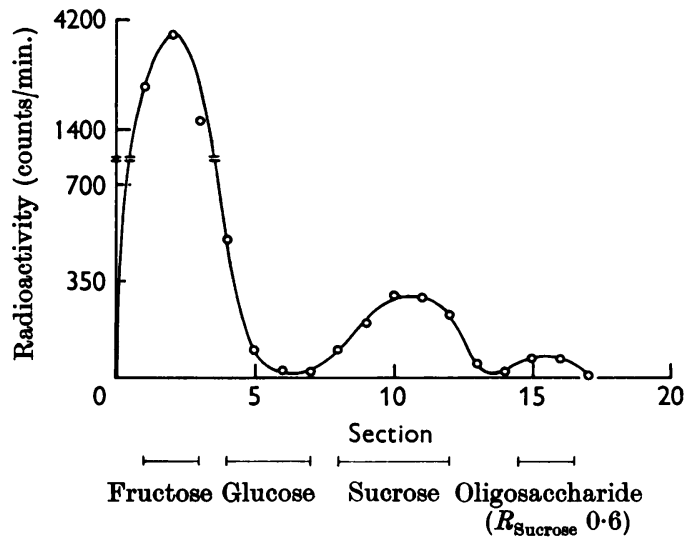

Fig. 4. Radioactivity of chromatographically separated sugars formed during incubation of rabbit intestinal invertase (fraction 2 ) with sucrose and $\left[{ }^{14} \mathrm{C}\right]$ fructose.

Samples from tube (4) showed the presence of glucose and fructose only. Samples from tubes (1), (2) and (3) showed the presence (benzidine spray reagent) of the oligosaccharide $\left(R_{\text {sucrose }} \quad 0 \cdot 6\right)$ mentioned above, sucrose, glucose and fructose. Figs. 4 and 5 show the results obtained on determining the radioactivity in successive sections of the paper to which a sample from tubes (2) and (3) respectively had been applied. Separate experiments showed that the [U-14 C]glucose and [U-14 C]fructose when chromatographed in the presence of carrier glucose and fructose respectively were free of any other radioactive or benzidine-positive material.

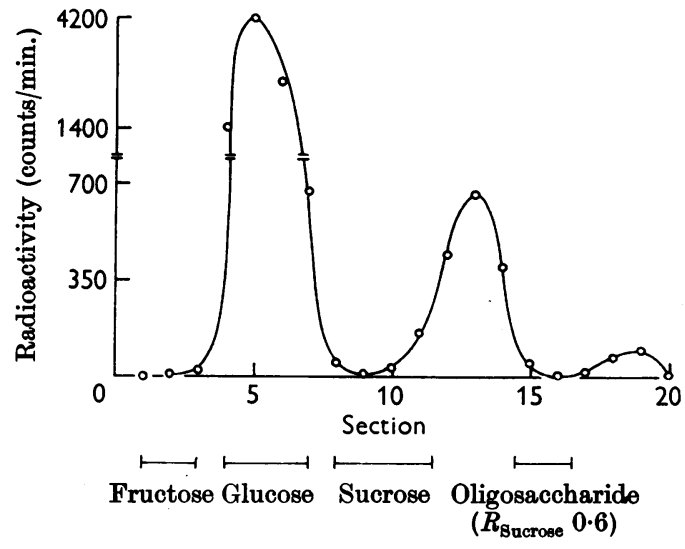

Fig. 5. Radioactivity of chromatographically separated sugars formed during incubation of rabbit intestinal invertase (fraction 2) with sucrose and $\left[{ }^{14} \mathrm{C}\right]$ glucose.

Fig. 4 indicates that the intestinal invertase formed sucrose and oligosaccharide. $\left(R_{\text {sucroese }} 0 \cdot 6\right)$ by transglucosylation from sucrose to free fructose. The radioactive areas of the chromatogram corresponded to benzidine-positive areas. The results shown in Fig. 5 complement those shown in Fig. 4; the invertase preparation did not form either sucrose or oligosaccharide $\left(R_{\text {sucrose }} 0 \cdot 6\right)$ by transfructosylation from sucrose to free glucose. Two areas of the chromatogram (Fig. 5) that failed to react with the benzidine spray reagent became labelled in the presence of $\left[{ }^{14} \mathrm{C}\right]$ glucose. These areas of the chromatogram lay immediately above and 
below the oligosaccharide of $R_{\text {sucrose }} \mathbf{0 \cdot 6}$. It was subsequently shown that the material in these areas ( $R_{\text {sucrose }} 0.8$ and 0.25 ) reacted slowly with an alkaline $\mathrm{AgNO}_{3}$ reagent. Sucrose and the oligosaccharide $\left(R_{\text {sucrose }} \mathbf{0 \cdot 6}\right)$ also reacted slowly with this reagent.

\section{DISCUSSION}

Partially purified preparations (fractions 3 and 4) of the invertase and maltase activities of the mucosal cells of rabbit upper intestine have been obtained. The activity of either of these preparations was considerably more stable than that of the crude starting material. In experiments designed to determine the optimum substrate concentration of the enzyme it was found that hydrolytic activity increased smoothly with increasing initial substrate concentration to approach maximum activity at $0.1 \mathrm{~m}$-sucrose. There was no discontinuity in the plot of enzyme activity against initial substrate concentration and no decrease in activity with increasing substrate concentration up to $0.5 \mathrm{M}$-sucrose. This contrasts with the situation reported for an invertase preparation obtained from three mixed species of protozoa (Christie \& Porteous, 1957; Carnie \& Porteous, 1959a) and for the invertase and maltase activity of hog intestine (Dahlqvist, 1960e). Evidence consistent with the formation of a substrate-activated enzyme-substrate complex (Fig. 3) must be treated with reserve until a more rigorously purified invertase preparation has been obtained from rabbit intestine.

It has been shown that incubation of sucrose with the partially purified invertase from rabbit intestine gave rise to three oligosaccharides $\left(R_{\text {sucroes }}\right.$ $0.8,0.6$ and 0.25 ). All three sugars reacted slowly with an alkaline silver nitrate reagent but only the sugar of $\boldsymbol{R}_{\text {sucrose }} \mathbf{0 . 6}$ reacted with a benzidine spray reagent and with the ketose-sensitive ureaphosphoric acid spray reagent.

Whereas plant, bacterial, fungal and protozoal invertases appear to be $\beta$-fructosidases (Edelman, 1956; Allen \& Bacon, 1956; Christie \& Porteous, 1957; Howard, 1959), the honey-bee enzyme (White \& Maher, 1953) and hog intestinal invertase (Dahlqvist, 1958, 1960c; Dahlqvist \& Borgström, 1959) are $\alpha$-glucosidases. In the present work it has been shown that the rabbit intestinal invertase also exhibited $\alpha$-glucosidase activity, since it apparently transferred the $\alpha$-glucosyl residue, but not the $\beta$-fructosyl residue, of sucrose to a suitable acceptor such as fructose. In this transfer reaction sucrose was resynthesized (Fig. 4); the only other invertase known to transfer a glycosyl residue to a hydroxyl group other than that of a primary alcohol or of water is a mould invertase (Edelman \& Bealing, 1953).
The oligosaccharide $\left(R_{\text {suorose }} 0 \cdot 6\right)$ was also presumably formed by transglucosylation from sucrose (Figs. 4 and 5); if the acceptor in this instance was sucrose, some of which had already become labelled with $\left[{ }^{14} \mathrm{C}\right]$ fructose, the product of the transfer reaction would have been a trisaccharide with a glucose: fructose ratio of 2 . Hydrolysis of the sugar $\left(R_{\text {Bucrose }} 0.6\right)$ showed that it contained glucose and fructose only and analysis showed that it had a glucose:fructose ratio approximating closely to unity (Table 2); its chromatographic mobility was consistent with that of a disaccharide. It would appear therefore that this sugar was formed by transglucosylation from sucrose to free fructose to give a disaccharide. Since the sugar also appeared to be essentially non-reducing it seemed improbable that it was iso-maltulose, leucrose or maltulose [6-O-, 5-O- or 4-O-( $\alpha$-D-glucopyranosyl)-D-fructose respectively]. Turanose [3$O$-( $\alpha$-D-glucopyranosyl)-D-fructose] was shown to have marked reducing power, giving about onethird of the extinction of an equal weight of glucose in the Nelson reaction; the new sugar was also distinguished from turanose since the latter had a chromatographic mobility essentially identical with that of sucrose in the solvent system used to separate sucrose and the new disaccharide. On the assumption that inversion about the anomeric carbon of glucose did not take place during transglucosylation, and that the glucosyl radical retained the pyran ring structure, the remaining possibilities are that the new disaccharide is 1.O. ( $\alpha$-D-glucopyranosyl)-D-fructose (Avigad, 1959), 2-O-( $\alpha$-D-glucopyranosyl)- $\alpha$-D-fructofuranoside, 2 . $O$-( $\alpha$-D-glucopyranosyl)- $\alpha$-D-fructopyranoside or 2 $O$-( $\alpha$-D-glucopyranosyl)- $\beta$-D-fructopyranoside. All of these sugars would be expected to react very slowly with the usual chromatographic alkaline silver nitrate reagents and to show little if any reducing power when tested with the alkaline copper sulphate reagent of Nelson (1944).

Transglucosylation from sucrose to the fructose moiety of another molecule of sucrose that had already become labelled with $\left[{ }^{14} \mathrm{C}\right]$ fructose (Fig. 4) would, as mentioned above, give a trisaccharide with a glucose: fructose ratio of 2. Subsequent hydrolysis of this trisaccharide by the enzyme so as to release the $\alpha$-glucosyl residue of the original sucrose molecule would leave a glucosylfructose labelled in the fructose moiety (cf. Fig. 4). If the glucosylfructose $\left(R_{\text {Bucrose }} 0 \cdot 6\right)$ was in fact formed by this mechanism, rather than by transglucosylation to free fructose, it could only have the first of the four possible structures mentioned above, assuming again that inversion about the anomeric carbon atom of glucose did not take place during transglucosylation and that the glucosyl residue retained its pyran ring structure. 


\section{SUMMARY}

1. Invertase and maltase have been detected in a centrifugally isolated particulate fraction of disrupted mucosal cells of rabbit small intestine. The preparation was free of lactase activity.

2. The crude enzyme preparation has been partially purified and a relatively stable and apparently soluble form of the two activities obtained.

3. The kinetic characteristics of the invertase activity have been determined.

4. Oligosaccharide formation by the enzyme preparation incubated with sucrose or with maltose has been demonstrated. In the presence of the latter substrate two oligosaccharides were formed, one of which was possibly maltotriose and the other possibly a tetrasaccharide.

5. The invertase activity has been characterized as an $\alpha$-glucosidase. On incubation with sucrose the enzyme incorporated $\left[{ }^{14} \mathrm{C}\right]$ fructose into sucrose and into another apparently non-reducing, benzidine-positive, glucosylfructose. Two benzidine-negative sugars were detected as products of the action of the enzyme on sucrose in the presence of $\left[{ }^{14} \mathrm{C}\right]$ glucose.

We thank the Medical Research Council for a Scholarship for Training in Research Methods awarded to J.A.C.

\section{REFERENCES}

Allen, P. J. \& Bacon, J. S. D. (1956). Biochem. J. 63, 200. Avigad, G. (1959). Biochem. J. 63, 587.

Bacon, J. S. D. (1952). Biochem. J. 50, xviii.

Bacon, J. S. D. \& Edelman, J. (1951). Biochem. J. 48, 114.

Bealing, F. J. (1953). Biochem. J. 55, 93.

Bealing, F. J. \& Bacon, J. S. D. (1953). Biochem. J. 53, 277.

Borgström, B. \& Dahlqvist, A. (1958). Acta chem. scand. $12,1997$.
Carnie, J. A. \& Porteous, J. W. (1959a). Biochem. J. 73, $47 \mathrm{P}$.

Carnie, J. A. \& Porteous, J. W. (1959b). Biochem. J. 73, 48 .

Carnie, J. A. \& Porteous, J. W. (1962). Biochem. J. (in the Press).

Chibnall, A. C., Rees, M. W. \& Williams, E. F. (1943). Biochem. J. 37, 354.

Christie, A. O. \& Porteous, J. W. (1957). Biochem. J.67, 19P.

Conway, E. J. \& O'Malley, E. (1942). Biochem. J. 36, 655.

Dahlqvist, A. (1958). Acta chem. scand. 12, 2012.

Dahlqvist, A. (1959a). Acta chem. scand. 13, 945.

Dahlqvist, A. (1959b). Acta chem. scand. 13, 1817.

Dahlqvist, A. (1959c). Acta chem. scand. 13, 2156.

Dahlqvist, A. (1960a). Acta chem. scand. 14, 1.

Dahlqvist, A. (1960b). Acta chem. scand. 14, 9.

Dahlqvist, A. (1960c). Acta chem. scand. 14, 63.

Dahlqvist, A. (1960d). Acta chem. scand. 14, 72.

Dahlqvist, A. (1960e). Acta chem. scand. 14, 1797.

Dahlqvist, A. (1960f). Hog Intestinal $\alpha$-Glucosidases. Lund, Sweden: Håken Ohlssons Boktryckeri.

Dahlqvist, A. (1961). Biochem. J. 78, 282.

Dahlqvist, A. \& Borgström, B. (1959). Acta chem. scand. 13, 1659 .

Dent, C. E., Stepka, W. \& Steward, F. C. (1947). Nature, Lond., 160, 682.

Dixon, M. \& Webb, E. C. (1958). Enzymes, p. 90. London: Longmans, Green and Co. Ltd.

Edelman, J. (1956). Advanc. Enzymol. 17, 189.

Edelman, J. \& Bealing, F. J. (1953). Biochem. J. 53, ii.

Howard, B. H. (1959). Biochem. J. 71, 675.

Lineweaver, H. \& Burk, D. (1934). J. Amer. chem. Soc. 56, 658.

Markham, R. (1942). Biochem. J. 36, 790.

Nelson, N. (1944). J. biol. Chem. 153, 375.

Partridge, S. M. (1948). Biochem. J. 42, 238.

Pavlinova, O. A. \& Kursanov, A. L. (1956). Fiziol. Biokhim. Anat. Rast. 3, 539.

Roe, J. H., Epstein, J. H. \& Goldstein, N. P. (1949). J. biol. Chem. 178, 839.

White, J. W. \& Maher, J. (1953). Arch. Biochem. Biophys. 42, 360.

Wise, C. S., Dimler, R. J., Rist, C. E. \& Davis, H. A. (1955). Analyt. Chem. 27, 33.

\title{
The Metabolism of Potassium L-Serine $O\left[{ }^{35} \mathrm{~S}\right]-$ Sulphate in the Rat
}

\author{
BY N. TUDBALL \\ Department of Biochemistry, University College, St Andrew's Place, Cardiff
}

\section{(Received 25 June 1962)}

Dodgson, Lloyd \& Tudball (1961 $a$ ) and Dodgson \& Tudball (1961) reported the presence in mammalian tissues of an enzyme system capable of bringing about the desulphation of L-serine $O$-sulphate in vitro. The enzyme is mainly located in the cell sap of rat liver and therefore coexists with the enzyme system which is responsible for the sulphation of alcohols, phenols and steroids (see Spencer, 1960; Roy, 1956). Dodgson \& Tudball (1961) have pointed out that the coexistence of desulphating and sulphating mechanisms could explain why it has not been possible to achieve the 